\title{
ANALISIS FAKTOR YANG MEMPENGARUHI PROFITABILITAS PADA SEKTOR PERBANKAN
}

\author{
Giovani Virza Amallia1, * \\ Program Studi Magister Manajemen, Universitas Hayam Wuruk Perbanas Surabaya, \\ Surabaya, Indonesia, gvnvirsa14@gmail.com \\ *Corresponding author \\ Suhartono ${ }^{2}$ \\ Program Studi Magister Manajemen, Universitas Hayam Wuruk Perbanas Surabaya, \\ Surabaya, Indonesia, suhartono@perbanas.ac.id
}

\begin{abstract}
Background - Bank can achieve their objective in making a profit by considering some factors. Among the factors considered are factors attached to the internal bank. Among other things, through the management of operational activities, it will impact the bank's performance over the resulting profitability ratios.
\end{abstract}

Diterima : 19 Juni 2021

Direview : 04 Agustus 2021

Direvisi : 31 Desember 2021

Disetujui : 31 Januari 2022

Aim - The purpose of this study was to examine the ratio of Loan to Deposit Ratio (LDR), Non Performing Loan (NPL), Bank Size, and Good Corporate Governance (GCG) partially to Return-On-Asset (ROA) in banking sector.

Design / methodology / approach - The population used in this study is banking in Indonesia. In this study using purposive sampling technique. The data source of this research uses quantitative secondary data. The analysis technique used in this research is multiple linear regression model.

Findings - The results of this show that Loan to Deposit Ratio has a significant positive effect on Return On Asset while the Non-Performing Loan ratio has an negative significant effect on Return On Asset. The Bank Size and Good Corporate Governance ratios have a insignificant negative influence on Return On Asset.

Research implication - Based on the results of tests that have been carried out previously, this study has managerial implications in reviewing what factors can increase profitability for Commercial Banks of Business Category 2.

Limitations - The research sample is limited to BUKU 2 only. The research period used is limited to 20152019. The factors that influence the Return On Asset are limited to internal factors.

Keyword : Bank, Size, GCG, LDR, NPL, ROA

\begin{abstract}
Abstrak
Latar Belakang - Bank dapat mencapai tujuannya dalam memperoleh laba dengan mempertimbangkan beberapa faktor. Faktor yang dipertimbangkan tersebut diantaranya merupakan faktor-faktor yang melekat pada internal bank. Diantaranya melalui pengelolaan kegiatan operasional sehingga hal tersebut akan berdampak pada perolehan kinerja bank yang tercermin melalui rasio profiabilitas yang dihasilkan. Tujuan - Untuk menganalisis pengaruh rasio Loan to Deposit Ratio, Non Performing Loan, Bank Size, dan Good Corporate Governance secara parsial maupun terhadap Return On Asset pada sektor Perbankan.

Desain / metodologi / pendekatan - Populasi yang digunakan dalam penelitian ini adalah Perbankan di Indonesia. Untuk menemukan sampel sesuai kriteria, melalui teknik purposive sampling. Sumber data penelitian ini menggunakan data sekunder yang bersifat kuantitatif. Teknik analisis yang digunakan pada penelitian ini yaitu regresi data panel.

Temuan - Hasil penelitian menunjukkan secara parsial Loan to Deposit Ratio memiliki pengaruh positif signifikan terhadap Return On Asset, sedangkan rasio Non Performing Loan memiliki pengaruh negatif signifikan terhadap Return On Asset. Adapun Rasio Bank Size dan Good Corporate Governance memiliki pengaruh yang negatif tidak signifikan terhadap Return On Asset.
\end{abstract}


Implikasi penelitian - Berdasarkan hasil pengujian yang telah dilakukan sebelumnya, penelitian ini memiliki implikasi manajerial dalam meninjau faktor apa saja yang dapat meningkatkan profitabilitas bagi Bank Umum Kategori Usaha (BUKU) 2.

Batasan penelitian - Sampel penelitian terbatas pada BUKU 2 saja, Periode penelitian yang digunakan terbatas pada tahun 2015 - 2019. Faktor-faktor yang mempengaruhi dihasilkannya Return On Asset terbatas pada faktor internal saja.

Kata kunci : Ukuran, Bank, GCG, $L D R, N P L, R O A$

\section{PENDAHULUAN}

Bank merupakan suatu lembaga keuangan yang berperan penting dalam perekonomian di Indonesia. Bank sendiri memiliki tugas dalam menghimpun dana masyarakat, kemudian menyalurkan kembali dana tersebut dalam bentuk pinjaman (financial intermediary). Industri perbankan merupakan salah satu bisnis yang berperan strategis untuk perkembangan suatu negara.Atas kestrategisan peran bank dalam menjaga stabilitas sistem keuangan, maka industri ini patut mendapat perhatian dari pemerintah. Sebab industri ini rentan akan risiko maupun kegagalan sistemik (Eng, 2013).

Laba bank akan tercapai dengan adanya keberagaman produk dan jasa pada industri ini. Keberagaman tersebut mendorong masing-masing pihak bank untuk berkompetisi dalam memberikan kualitas dan layanan terbaiknya. Hal tersebut dilakukan untuk menarik minat nasabah agar bertransaksi menggunakan layanan perbankan.

Peraturan Otoritas Jasa Keuangan No. 6/POJK.03/2016 yang mengatur kegiatan usaha berdasarkan modal inti bank. Peran modal inti tersebut akan menjadi faktor krusial yang diyakini dapat menjadi ketahanan bagi bank guna memperoleh peningkatan laba (Darina et al., 2020). Kegiatan usaha berdasarkan modal inti bank terdiri dari BUKU 1, BUKU 2, BUKU 3, dan BUKU 4. Berikut perkembangan laba bank berdasarkan kategori usahanya. Pada gambar 1, terlihat perkembangan laba setelah pajak dari tahun 2015-2019 yang menunjukkan adanya fluktuasi. Laba yang dihasilkan tersebut berkaitan dengan biaya yang dikeluarkan guna kegiatan operasional bank. Laba yang dihasilkan tersebut berkaitan dengan biaya yang dikeluarkan guna kegiatan operasional bank. Pada gambar tersebut terlihat BUKU 2 menghadapi tekanan yang signifikan. Hal ini tercermin pada perolehan laba yang sempat mengalami kenaikan pada tahun 2016 hingga lambat laun kian menurun. Hal tersebut mengindikasikan atas adanya suatu masalah bisnis yang sedang dihadapi. Dimana penurunan tersebut berkaitan 
dengan kurang optimalnya kegiatan usaha yang dilakukan.

Pembatasan kegiatan usaha yang berlaku pada BUKU 2 menjadi salah satu dampak penurunan laba. Bank dengan kategori ini hanya dapat melakukan layanan treasury terbatas dan penyertaan modal pada lembaga keuangan dalam negeri saja. Hal ini mengakibatkan pangsa pasar yang dimiliki pun relatif terbatas. Potensi akan laba yang dihasilkan pun juga akan terpengaruh oleh target pasar yang juga terbatas. Kegagalan bisnis dapat diminimalisir dengan adanya pengendalian internal. Pengendalian tersebut diterapkan agar keberlangsungan bisnis bank dapat tetap berjalan dengan baik. Bank patut mempertimbangkan faktor yang menjadi masalah dalam proses perolehan laba. Faktor yang dipertimbangkan tersebut diantaranya merupakan faktor-faktor yang melekat pada internal bank diantaranya melalui rasio perbankan.

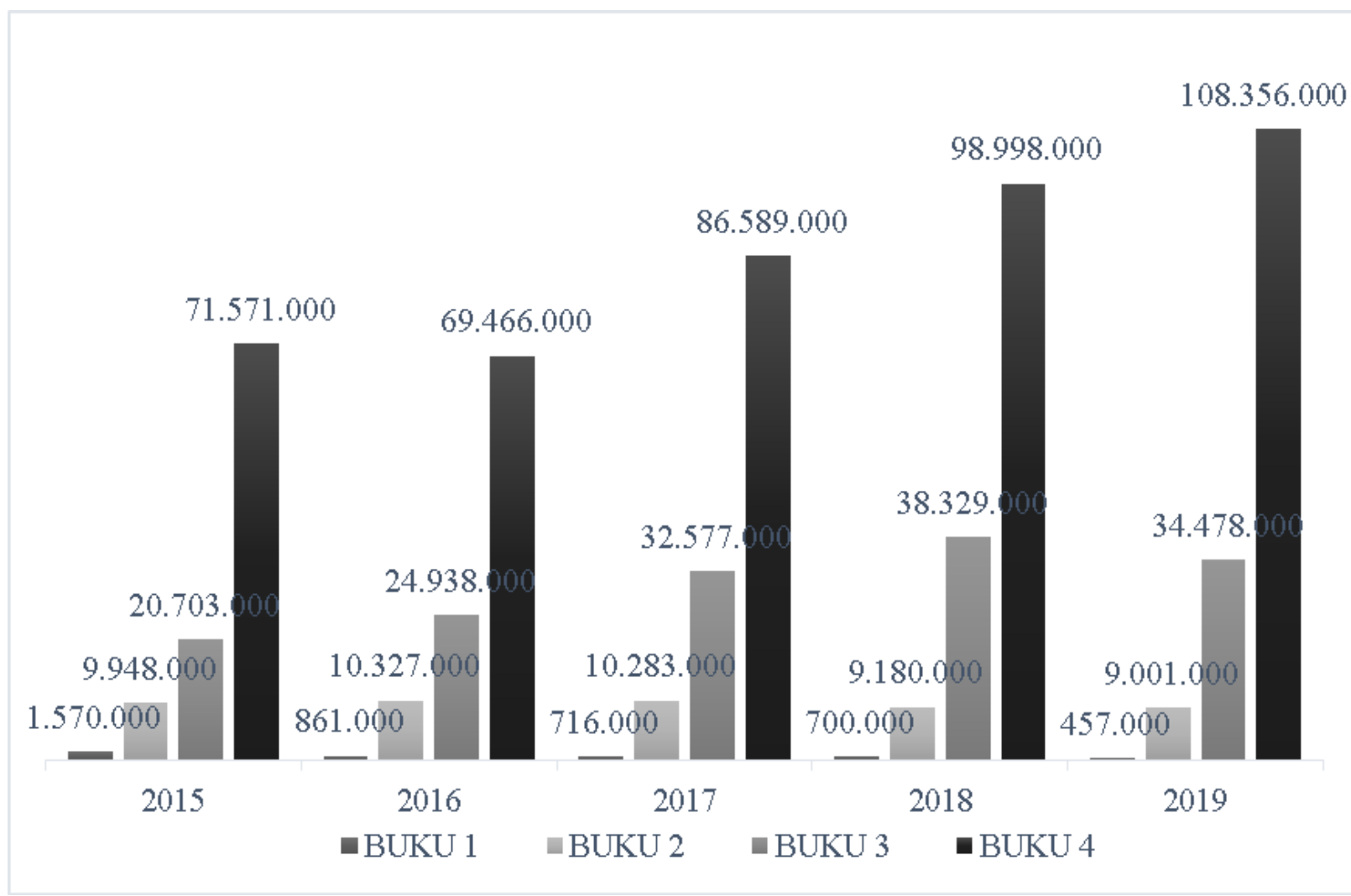

Sumber : Laporan Publikasi Keuangan OJK per Desember 2019

Gambar 1

Perkembangan Laba Setelah Pajak Bank (dalam Jutaan Rupiah)

Rasio perbankan berfungsi sebagai salah satu tolak ukur kemampuan bank dalam menghasilkan laba. Pada pengukuran laba bank dapat dievaluasi melalui rasio profitabilitas. Tolak ukur yang digunakan dalam rasio ini melalui rasio ROA. Rasio ini 
memanfaatkan informasi laba bersih sebelum pajak terhadap total aset yang dimiliki bank. Apabila bank dapat mengelola laba yang dihasilkan secara efektif dan efisien, maka bank dapat melakukan perluasan aset maupun investasinya guna mendukung keberlangsungan proses bisnis (Alhempi, 2016).

Rasio berikutnya yang memberikan pengaruh terhadap dihasilkannya suatu laba diantaranya rasio likuiditas. Rasio likuiditas merupakan tolak ukur kemampuan bank dalam memenuhi kewajiban jangka pendeknya pada pihak ketiga. Salah satu rasio yang dapat mengukur tingkat likuiditas bank dengan menggunakan LDR. Rasio yang juga dapat mempengaruhi laba yang dihasilkan bank ialah rasio kualitas aset. Rasio ini digunakan untuk mengetahui kemampuan kualitas aset lancar yang dimiliki bank dalam menutup aset produktif bermasalah. Aset produktif tersebut dialokasikan pada kegiatan bank berupa penyaluran kredit.

Tingkat kesehatan bank dapat diproyeksikan melalui rasio NPL). Rasio ini memanfaatkan informasi total kredit bermasalah terhadap total kredit yang diberikan. Apabila bank memiliki nilai rasio yang tinggi, maka dapat dikatakan bank memiliki skor kesehatan yang tidak baik. Hutagalung (2013) dan Subandi (2013) membuktikan terdapat hubungan negatif signifikan antara NPL terhadap ROA. Tingginya kredit macet akan mempengaruhi penurunan profitabilitas yang dihasilkan. Berlawanan dengan hasil penelitian tersebut, Irawati et al., 2019 berpendapat bahwa NPL memiliki pengaruh negatif tidak signifikan terhadap ROA. Disamping itu, manajemen bank juga perlu memperhatikan faktor yang mempengaruhi profitabilitas selain rasio keuangan. Salah satu faktor tersebut ialah bank size. Bank size sendiri merupakan gambaran besar atau kecilnya suatu bank dengan menggunakan informasi total aset yang dimiliki. Apabila bank memiliki total aset yang tinggi maka bank diindikasikan memiliki struktur biaya yang lebih baik. Menurut Seemule et al., 2017 dan Sugiarto (2018) membuktikan bahwa bank size yang tinggi akan lebih menguntungkan dibandingkan dengan bank size rendah. Dengan demikian, bank size memiliki pengaruh positif signifikan terhadap ROA yang dihasilkan. Sebaliknya, Prasanjaya (2013) menyatakan bank size tidak memiliki pengaruh yang signifikan terhadap profitabilitas yang dihasilkan.

Selanjutnya faktor yang tidak kalah penting dalam mendorong pencapaian tujuan bank yaitu penerapan GCG. Penerapan sistem ini dilakukan secara jangka panjang dengan mempertimbangkan serangkaian kebijakan, proses, serta memperhatikan peraturan yang berlaku disuatu lembaga (Iramani et al., 2018). Penerapan prinsip GCG dapat ditempuh dengan beberapa cara, diantaranya melalui tolak ukur skor komposit self-assessment 
yang dimiliki bank. Dimana skor komposit bank menunjukkan nilai yang semakin kecil, maka bank telah menerapkan GCG dengan baik. Apabila bank yang telah menerapkan prinsip-prinsip GCG dengan baik, maka akan menghasilkan nilai tambah bagi pihak internal maupun eksternal bank. Hal ini sejalan dengan hasil penelitian yang dilakukan Ghalib (2018) dan Iramani et al., 2018 menyatakan bahwa hubungan antara GCG dengan profitabilitas ialah positif signifikan. Sebaliknya, Ferdyant et al., 2014 menyatakan GCG memiliki pengaruh negatif signifikan terhadap ROA.

\section{TINJAUAN PUSTAKA}

Pada penelitian ini, menggunakan beberapa teori yang berhubungan dengan pokok pembahasan penelitian. Teori-teori tersebut digunakan sebagai penunjang dalam penjelasan dan analisis yang akan dilakukan.

\section{Bank Umum}

Bank memiliki peran dalam meningkatkan taraf hidup masyarakat dalam membantu lalu lintas pembayaran. Menurut Berger et al., 2008 bank umum dapat diklasifikasikan berdasarkan kepemilikannya sebagai berikut

1. Bank Swasta dan Bank Negara

Pada klasifikasi ini, bank dikategorikan sesuai kepemilikan instansinya.Lebih dari 50\% kepemilikan bank swasta dikuasai oleh pihak swasta, baik nasional maupun asing.

2. Bank Domestik dan Bank Asing
Pada klasifikasi ini, jenis bank ditentukan berdasarkan kepemilikan suatu negara atau wilayahnya. Kepemilikan tersebut melalui kepemilikan nasional ataupun kepemilikan asing.

Sesuai Peraturan Otoritas Jasa Keuangan No. 6/POJK.03/2016 bank umum dapat dikelompokkan berdasarkan kegiatan usaha sebagai berikut :

1. BUKU 1, terdiri dari bank dengan modal inti bank sampai dengan kurang dari Rp. 1 Triliun.

2. BUKU 2, terdiri dari bank dengan modal inti paling sedikit $\mathrm{Rp} 1$ Triliun sampai dengan kurang dari Rp. 5 Triliun.

3. BUKU 3, terdiri dari bank dengan modal inti paling sedikit Rp. 5 Triliun sampai dengan kurang dari Rp. 30 Triliun.

4. BUKU 4, terdiri dari bank dengan modal inti paling sedikit Rp. 30 Triliun. Pada kategori ini cakupan aktivitas yang dilakukan lebih luas.

\section{Rasio Profitabilitas (ROA)}

Rasio profitabilitas digunakan untuk mengukur kemampuan bisnis yang dilakukan bank secara efisien dari keuntungan yang dicapai (Rivai, 2013). Pada rasio profitabilitas terdiri dari dua sudut pandang indikator penilaian. Sudut pandang tersebut akan menentukan bagaimana bank dapat mencapai profit tersebut. Adapun dua sudut pandang tersebut dari segi penjualan dan segi investasi. Namun, pada penelitian 
ini terfokuskan pada indikator penilaian segi investasi, sehingga penelitian ini menggunakan tolak ukur ROA. Rumus ROA ditunjukkan pada persamaan (1).

\section{Rasio Likuiditas (LDR)}

Rasio likuiditas merupakan rasio yang mempertimbangkan aset likuidnya yang digunakan untuk mengukur kemampuan bank dalam membayar tagihan jangka pendeknya (Salike, N., 2018). Penelitian ini berfokus pada pengukuran dengan rasio LDR. Rasio ini digunakan untuk mengukur kemampuan bank dalam memenuhi kewajibannya kepada nasabah yang menyimpan dananya mengggunakan aset likuid yang dimiliki pada bank. Rumus LDR ditunjukkan pada persamaan (2).

\section{Rasio Kualitas Aset (NPL)}

Rasio kualitas aset merupakan rasio yang digunakan untuk mengukur kemampuan kualitas aset lancar yang dimiliki bank.
Rasio ini sebagai tolak ukur kualitas aset lancar yang dapat menutup aset produktif yang diklasifikasikan berupa penyaluran kredit. Rasio ini dapat diproksikan dengan Non Performing Asset (NPA) dan Non Performing Loans (NPL). Rasio NPL merupakan rasio yang digunakan untuk mengukur tingkat kesehatan melalui manajemen bank.Pengukuran pada rasio ini dengan mempertimbangkan pengelolaan aset produktif yang baik. Rumus NPL ditunjukkan pada persamaan (3).

\section{Bank Size}

Salah satu tujuan bank dalam beroperasi ialah bagaimana bank dapat menghasilkan profit atau laba. Laba yang dihasilkan tersebut dapat diproyeksikan dengan ukuran besar atau kecilnya suatu bank. Bank size merupakan jumlah aset yang dimiliki oleh bank (Sugiarto, 2018).

$$
\begin{aligned}
& \text { ROA }=\frac{\text { Laba bersih sebelum pajak }}{\text { Total Aset }} \times 100 \% \\
& \text { LDR }=\frac{\text { Total kredit yang diberikan }}{\text { Total DPK }} \times 100 \% \\
& \text { NPL }=\frac{\text { Total Kredit Bermasalah }}{\text { Total Kredit }} \times 100 \% \\
& \text { Size }=\text { Ln Total Aset }
\end{aligned}
$$




\section{Good Corporate Governance (GCG)}

Teori keagenan merupakan hal dasar yang perlu diperhatikan dalam penerapan good corporate governance. Teori ini menjelaskan bahwa manajemen bank perlu adanya bantuan pihak profesional agar kegiatan operasional dapat berjalan secara efektif dan efisien. Menurut Rahayu, (2018) good corporate governance dapat mewujudkan manfaat jangka panjang pada perusahaan. Good corporate governance pada bank akan terlaksana apabila menerapkan beberapa prinsip yaitu Transparency, Accountability, Responsibility, Independency, Fairness. Penerapan GCG yang baik dapat diukur dengan menggunakan nilai resiprokal yang diperoleh dari nilai komposit bank sebagai berikut

Tabel 1

Nilai komposit good corporate governance

\begin{tabular}{lll}
\multicolumn{1}{c}{ Skor Komposit } & \multicolumn{1}{c}{ Predikat } & \multicolumn{1}{c}{ Resiprokal } \\
Skor komposit $<1,5$ & Sangat Baik & 6- Skor komposit \\
$1,5<$ Skor komposit $<2,5$ & Baik & 6-Skor komposit \\
$2,5<$ Skor komposit $<3,5$ & Cukup & 6-Skor komposit \\
$3,5<$ Skor komposit $<4,5$ & Kurang Baik & 6-Skor komposit \\
$4,5<$ Skor komposit $<5$ & Tidak Baik & 6- Skor komposit \\
\hline Sumber: SEBI No. 9/12/DPNP & &
\end{tabular}

\section{Kerangka Penelitian}

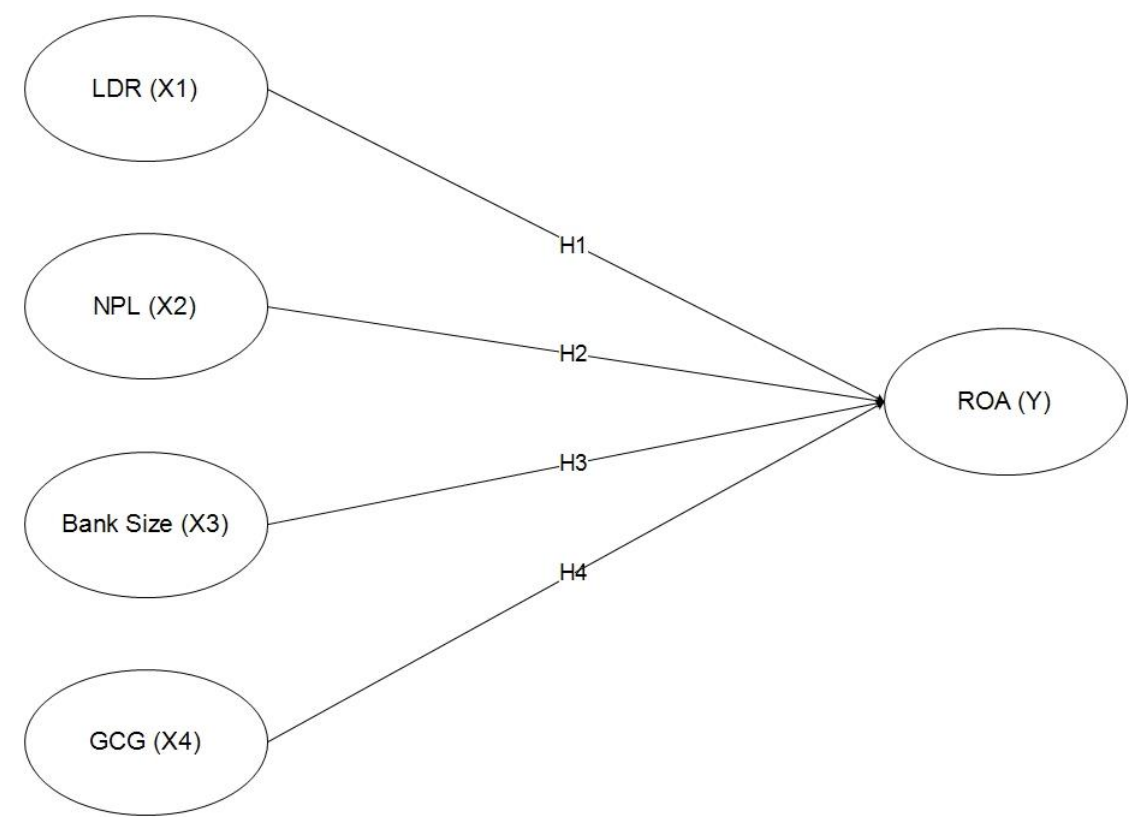

Gambar 2

Kerangka Penelitian 


\section{Hipotesis}

H1 : LDR secara parsial memiliki pengaruh signifikan terhadap ROA.

H2 : NPL secara parsial memiliki pengaruh negatif signifikan terhadap ROA.

H3 : Bank Size secara parsial memiliki pengaruh positif signifikan terhadap ROA.

H4 : GCG secara parsial memiliki pengaruh signifikan terhadap ROA.

\section{METODOLOGI PENELITIAN}

Penelitian ini termasuk dalam studi kausal yang dilakukan untuk mengetahui hubungan saling mempengaruhi antar variabel. Studi ini menggunakan hipotesis yang juga mempertimbangkan peristiwa yang telah terjadi sebagai alat bantu pada pengujiannya.

Berdasarkan sumber data, sumber data penelitian ini menggunakan data sekunder yang bersifat kuantitatif. Pendekatan kuantitatif ini menggunakan sekumpulan informasi berupa angka dan dapat dianalisis untuk proses pengambilan keputusan (Kuncoro, 2009).

Populasi penelitian yang digunakan adalah Perbankan di Indonesia. Pada penelitian ini menggunakan teknik purposive sampling, dimana teknik pengambilan sampel berdasarkan sumber data dengan pertimbangan tertentu (Sugiyono, 2015). Dari populasi tersebut, didapatkan 29 bank sampel sesuai dengan kriteria yang telah ditetapkan sebagai berikut:
1. Bank yang termasuk pada kategori BUKU 2 per Desember 2019.

2. Bank yang menerbitkan laporan tahunan secara berkala dari 2015-2019.

3. Bank yang memiliki rata-rata tren ROA negatif periode 2015-2019.

\section{Teknik Analisis Data}

Teknik analisis yang digunakan pada penelitian ini yaitu analisis regresi data panel. Analisis ini menyediakan lebih banyak data akibat pemanfaatan kombinasi data time series dan cross section. Berikut adalah langkah - langkah melakukan analisis tersebut :

1. Uji Asumsi Klasik

Pada penelitian data panel diperlukan pengujian asumsi klasik. Pengujian ini dilakukan pada model regresi linear dengan pendekatan Ordinary Least Square (OLS). Pendekatan tersebut digunakan pada penelitian dengan model Common Effect maupun Fixed Effect. Dengan demikian penelitian ini hanya menggunakan uji asumsi klasik yang terdiri dari (1) uji normaltas, (2) uji multikolineritas, (3) uji autokorelasi, dan (4) uji heteroskedasitas.

2. Analisis Regresi Data Panel

Metode analisis ini digunakan untuk mengetahui variasi-variasi hubungan yang dihasilkan antar dua variabel atau lebih. Pada metode analisis ini juga memiliki kegunaan untuk mengetahui besarnya pengaruh variabel. Analisis ini 
dapat menyediakan lebih banyak data akibat pemanfaatan kombinasi data time series dan cross section. Adapun model regresi secara umum yang akan dihasilkan variabel independen terhadap variabel dependen (persamaan 5).
3. Uji Hipotesis

Pada sub bab ini akan dilakukan pengujian terhadap hipotesis yang telah ditentukan sebelumnya. Penelitian ini akan menggunakan uji hipotesis parsial (uji t) dan koefisien determinasi (uji $R^{2}$ )

$$
Y_{i t}=\alpha_{i t}+\beta 1 X 1+\beta 2 X 2+\beta 3 X 3+\beta 4 X 4+e_{i t}
$$

Keterangan:

$Y_{i t}=$ Return On Asset

$\mathrm{a}=$ Konstanta

$\beta_{1}-\beta_{4}=$ Koefisien Regresi

$\mathrm{X}_{1}=\mathrm{LDR}$

$\mathrm{X}_{2}=\mathrm{NPL}$

$\mathrm{X}_{3}=$ Bank Size

$\mathrm{X}_{4}=\mathrm{GCG}$

$\mathrm{e}=$ Error

\section{HASIL DAN PEMBAHASAN}

\section{Uji Asumsi Klasik}

Setelah diketahui model regresi terbaik yang akan digunakan, maka pengujian dilanjutkan dengan uji asumsi klasik dengan hasil sebagai berikut

1. Uji Normalitas

Berikut hasil yang diperoleh melalui Shapiro Wilk, dimana nilai Prob $>Z$ sebesar $0,00<0,05$. Hal ini membuktikan adanya pelanggaran uji normalitas atau data terdistribusi tidak normal. Hasil uji normalitas ditunjukkan pada tabel 2 .

2. Uji Multikolinearitas

Adapun pengujian multikolinearitas yang telah dilakukan memperoleh hasil sebagaimana ditunjukkan pada tabel 3 . Pada tabel 3 hasil pengujian diatas menunjukkan bahwa nilai VIF masingmasing variabel LDR sebesar 36,07, NPL sebesar 3,36, Bank Size sebesar 142,32, dan GCG sebesar 79,53. Nilai VIF dengan hasil kurang dari 10, hanya pada variabel NPL. Artinya hanya variabel NPL terbukti tidakberkorelasi dengan variabel independen lain yang digunakan.

3. Uji Autokorelasi

Pada penelitian ini, uji autokorelasi menggunakan Wooldrige untuk memenuhi kriteria uji asumsi klasik. Hasil pengujian (tabel 4) menunjukkan bahwa nilai $\mathrm{P}$ sebesar 0,01. Nilai ini kurang dari 0,05, sehingga dapat disimpulkan adanya autokorelasi pada penelitian.

4. Uji Heteroskedastisitas 


$\begin{array}{ll}\text { Berikut merupakan hasil pengujian } & \text { kurang dari 0,05, sehingga dapat } \\ \text { heteroskedastisitas dengan Breusch- } & \text { diartikan adanya heteroskedastisitas } \\ \text { Pagan. Pada tabel } 5 \text { nilai signifikansi } & \text { (data heterogen) pada variabel } \\ \text { yang ditunjukkan melalui Prob }>\text { Chi2 } & \text { penelitian. }\end{array}$
sebesar 0,00. Artinya nilai tersebut

Tabel 2

Hasil uji normalitas

$\begin{array}{ll}Z & 3,87 \\ \text { Prob }>Z & 0,00\end{array}$

Sumber : data diolah, 2021

Tabel 3

Hasil uji multikolinearitas

\begin{tabular}{lrr}
\multicolumn{1}{c}{ Variabel } & \multicolumn{1}{c}{ VIF } & $1-$ VIF \\
LDR & 36,07 & 0,03 \\
NPL & 3,36 & 0,29 \\
Bank Size & 142,32 & 0,00 \\
GCG & 79,53 & 0,01 \\
\hline Sumber : data diolah, 2021 & &
\end{tabular}

Tabel 4

Hasil uji autokorelasi

\begin{tabular}{ll}
$\mathrm{F}(1,28)$ & 6,80 \\
Prob $>$ F & 0,01 \\
\hline Sumber : data diolah, 2021 &
\end{tabular}

Tabel 5

Hasil uji heteroskedastisitas

\begin{tabular}{lr} 
Chi (1) & 7372,50 \\
Prob > Chi & 0,00 \\
\hline
\end{tabular}

Sumber : data diolah, 2021

\section{Uji Estimasi Model Regresi}

Penelitian ini ini menggunakan data panel yang mengkombinasikan data time series dan cross section. Pengujian ini memerlukan estimasi untuk menentukan model regresi terbaik dengan menggunakan dua metode berikut:
1. Chow Test

Metode ini dilakukan guna mengetahui model terbaik diantara Ordinary Least Square (OLS) dan Fixed Effect (FE) dengan hipotesis HO : Ordinary Least Square (OLS) H1 : Fixed Effect (FE) 
Pada tabel 6 menunjukkan bahwa nilai P yang ditunjukkan pada kolom Prob > $\mathrm{F}$ sebesar $0,00<0,05$. Artinya $\mathrm{H}_{1}$ diterima, dimana model regresi terbaik pada pengujian ini menggunakan Fixed Effect (FE).

\section{Hausman Test}

Apabila pada pengujian sebelumnya diperoleh model terbaik menggunaan Fixed Effect, maka diperlukan pengujian lebih lanjut dengan metode Hausman Test. Pengujian ini dilakukan untuk menentukan kembali apakah teknik sebelumnya Fixed Effect (FE) lebih baik dibandingkan dengan Random Effect (RE). Adapun hipotesis sebagai berikut :

HO : Random Effect (RE)

H1 : Fixed Effect (FE)
Pada tabel 7 menunjukkan bahwa nilai Prob $>$ Chi2sebesar 0,01<0,05. Hal ini berarti $\mathrm{H}_{0}$ ditolak, sehingga model regresi terbaik pada penelitian ini menggunakan model Fixed Effect (FE).

\section{Analisis Regresi Data Panel}

Pada pengujian sebelumnya telah ditentukan model regresi terbaik yang akan digunakan pada penelitian, yaitu model Fixed Effect (FE). Selain itu, model regresi juga telah dinyatakan layak dari uji asumsi klasik, sehingga hasil estimasi penelitian akan konsisten dan tidak bias. Tabel 8 menunjukkan hasil pengujian analisis regresi data panel. Dari hasil analisis yang ditunjukkan pada tabel 8 diperoleh model regresi sebagai berikut

$$
R O A=\alpha_{i t}+0,02 L D R-0,13 N P-0,37 \text { Bank Siz }-0,18 G C G+e_{i t}
$$

Keterangan :

1. $\mathrm{Y}=\mathrm{ROA}$, sebagai variabel dependen.

2. Konstanta $\left(\alpha_{i t}\right)=7,32$, artinya LDR, NPL, Bank Size, dan GCG memiliki nilai yang constant sebesar 7,32 dalam mempengaruhi ROA.

3. $\quad \beta 1=0,02$, artinya jika LDR mengalami peningkatan sebesar satu persen maka ROA akan naik sebesar 0,02 persen.

4. $\quad \beta 2=-0,13$, artinya jika NPL mengalami peningkatan sebesar satu persen maka ROA akan turun sebesar 0,13 persen.

5. $\quad \beta 3=-0,37$, artinya jika Bank Size mengalami peningkatan sebesar satu persen maka ROA akan turun sebesar 0,37 persen.

6. $\beta 4=-0,18$, artinya jika GCG mengalami peningkatan sebesar satu persen maka ROA akan turun sebesar 0,18 persen. 
Tabel 6

Hasil Chow Test

\begin{tabular}{lrr}
\multicolumn{1}{c}{ Variabel Koef. Regresi } & $\mathrm{P}>|\mathrm{t}|$ \\
LDR & 0,02 & 0,03 \\
NPL & $-0,13$ & 0,00 \\
Bank Size & $-0,37$ & 0,20 \\
GCG & $-0,18$ & 0,39 \\
\hline Prob > F & & 0,00 \\
\hline Sumber : data diolah, 2021 & &
\end{tabular}

Tabel 7

Hasil Hausman Test

\begin{tabular}{lrr}
\multicolumn{1}{c}{ Variabel } & \multicolumn{2}{c}{ Koef. Regresi } \\
LDR & 0,02 & \multicolumn{1}{c}{ RE } \\
NPL & $-0,13$ & 0,02 \\
Bank Size & $-0,37$ & $-0,15$ \\
GCG & $-0,18$ & $-0,15$ \\
\hline Prob $>$ Chi2 & & $-0,44$ \\
\hline Sumber : data diolah, 2021 & & 0,01 \\
\hline
\end{tabular}

Tabel 8

Hasil Uji Analisis Regresi Data Panel

\begin{tabular}{lrrr} 
Variabel Koef. Regresi & \multicolumn{1}{c}{$\mathrm{t}$} & $\mathrm{P}>|\mathrm{t}|$ \\
LDR & 0,02 & 2,21 & 0,03 \\
NPL & $-0,13$ & $-3,04$ & 0,00 \\
Bank Size & $-0,37$ & $-1,29$ & 0,20 \\
GCG & $-0,18$ & $-0,85$ & 0,39 \\
Cons & 7,32 & 1,51 & 0,13 \\
Overall R-Squared & & & 0,17 \\
F (4, 112) & & 4,95 \\
\hline Prob $>$ F & & 0,00 \\
\hline Sumber : data diolah, 2021 & &
\end{tabular}

\section{Uji Hipotesis}

berdasarkan pengujian hipotesis pada penelitian dilakukan dengan beberapa tahapan serta menghasilkan keluaran yang menjelaskan hubungan kerangka hipotesa diatas sebagai berikut

1. Uji Parsial (Uji t)

Uji parsial dikenal juga dengan uji parameter individual. Pengujian ini dilakukan untuk mengetahui pengaruh variabel independen secara individual terhadap variabel dependen. Hasil analisis yang dilakukan peneliti dapat dijelaskan sebagai berikut :

a. Rasio Likuiditas (LDR)

Berdasarkan tabel 8 menunjukkan bahwa nilai $\mathrm{P}$ dapat menjelaskan nilai signifikansi sebesar 0,03 lebih 
kecil dari 0,05. Disamping itu, nilai t hitung yang dihasilkan sebesar 2,21 juga lebih besar dari t tabel yaitu 1,65. Artinya LDR memberikan pengaruh positif signifikan terhadap ROA, sehingga hipotesis diterima.

b. Kualitas Aset (NPL)

Pada tabel 8 menjelaskan bahwa nilai signifikansi variabel NPL sebesar 0,00 dengan nilai $t$ hitung sebesar -3,04. Hal ini dapat diartikan nilai signifikansi $0,00<$ 0,05 dan nilai t hitung $-3,04<-1,65$, sehingga $\mathrm{H}_{0}$ ditolak. Hipotesis NPL memiliki pengaruh negatif signifikan terhadap ROA dapat dibenarkan.

c. Bank Size

Berdasarkan tabel 8 dapat diketahui nilai $P$ sebesar 0,20 yang berarti lebih besar dari 0,05. Selain itu, nilai t hitung yang dihasilkan sebesar 1,29, dimana nilai ini lebih kecil dari t tabel yaitu 1,65. Dengan demikian, dapat disimpulkan bahwa hipotesis Bank Size secara parsial memiliki pengaruh positif signifikan terhadap ROA ditolak atau $\mathrm{H}_{0}$ diterima

d. Good Corporate Governance

Berdasarkan hasil pengujian pada tabel 8 menunjukkan bahwa nilai $\mathrm{P}$ yang dihasilkan sebesar 0,39 dengan nilai t hitung sebesar $-0,85$. Hal ini berarti nilai signifikansi 0,39>0,05, dan nilai $\mathrm{t}$ hitung $-6,22<-1,65$, sehingga HO diterima. Artinya hipotesis GCG secara parsial memiliki pengaruh signifikan terhadap ROA dapat ditolak.

\section{Koefisien Determinasi (Uji $\mathbf{R}^{\mathbf{2}}$ )}

Tahap pengujian ini dilakukan guna mengukur kemampuan model variabel independen dalam menjelaskan variabel dependennya. Berdasarkan tabel 8 menunjukkan hasil analisis nilai $R$-Squared sebesar 0,17 atau $17 \%$. Hal ini berarti bahwa variasi pada variabel LDR, NPL, Bank Size, dan GCG dapat mempengaruhi ROA sebesar $17 \%$. Sisanya sebesar $83 \%$ dipengaruhi oleh variabel lain diluar model penelitian.

\section{KESIMPULAN}

Berdasarkan analisis data yang telah dilakukan sebelumnya, maka diperoleh kesimpulan sebagai berikut :

1. LDR secara parsial memiliki pengaruh positif signifikan terhadap ROA pada Perbankan di Indonesia. Hal ini menunjukkan apabila LDR semakin meningkat, maka ROA yang dihasilkan juga akan mengalami peningkatan.

2. NPL secara parsial memiliki pengaruh negatif signifikan terhadap ROA. Hal ini menunjukkan bahwa semakin rendah NPL yang dimiliki bank, akan mempengaruhi tingginya ROA yang akan dihasilkan.

3. Bank Size secara parsial berpengaruh negatif tidak signifikan terhadap ROA. 
Artinya peningkatan Bank Size yang dimiliki bank, akan berbanding terbalik dengan semakin menurunnya ROA namun tidak signifikan.

4. GCG secara parsial berpengaruh negatif tidak signifikan terhadap ROA. Dengan demikian, GCG yang ditunjukkan melalui skor komposit yang semakin kecil maka ROA yang dihasilkan akan meningkat namun tidak signifikan.

\section{IMPLIKASI PENELITIAN}

Berdasarkan pengujian yang telah dilakukan, memperoleh hasil bahwa ROA yang dihasilkan bank dominan dipengaruhi oleh faktor kreditnya. Hal ini dipengaruhi baik dari segi penyaluran maupun kualitas kredit yang dihasilkan. ROA yang dimiliki bank akan menurun apabila rasio LDR maupun NPL tidak dikelola dengan baik. Dalam menjalankan tugas sebagai lembaga intermediasi, bank perlu memperhatikan prinsip-prinsip pokok perbankan. Diantaranya dengan mempertimbangkan prinsip prudent, yang mana bank wajib bersikap berhati-hati dalam melindungi dana nasabah yang dikelola oleh bank. Prinsip ini bertujuan untuk meminimalisir adanya risiko kredit yang timbul.

\section{ACKNOWLEDGEMENT}

Peneliti mengucapkan terima kasih kepada pihak-pihak yang terlibat dalam disusunnya penelitian ini, khususnya pihak kampus Universitas Hayam Wuruk Perbanas Surabaya.

\section{DAFTAR PUSTAKA}

Alhempi, R. R., \& Zainal, H. (2016). Penentu Profitabilitas Perbankan Indonesia: Aplikasi Model Regresi Data Panel. MLX: Jurnal Ilmiah Manajemen, 6(1), 152412.

Berger, A. N., Klapper, L. F., Peria, M. S. M., \& Zaidi, R. (2008). Bank ownership type and banking relationships. Journal of Financial Intermediation, 17(1), 37-62.

Darina, P., Azam, A. N., \& Bayu, B. (2020). Analysis Causality Of Capital Structure And Profitability Of Banking Sector Listed In Indonesian Stocks Exchange: Buku 1, Buku 2, Buku 3, And Buku 4 Of 2014-2018 Period. Russian Journal of Agricultural and SocioEconomic Sciences, 97(1).

Eng, T. S. (2013). "Pengaruh NIM, BOPO, LDR, NPL \& CAR Terhadap Roa Bank Internasional Dan Bank Nasional Go Public Periode 2007-2011”. Jurnal dinamika manajemen, 1(3).

Ferdyant, F., Zr, R. A., \& Takidah, E. (2014). Pengaruh Kualitas Penerapan Good Corporate Governance dan Risiko Pembiayaan terhadap Profitabilitas Perbankan Syariah. Jurnal Dinamika Akuntansi dan Bisnis, 1(2), 134-149.

Ghalib, S. (2018). Good Corporate Governance Rating and Bank Profitability in Indonesia: Evidence from Panel Data. International Journal of Business \& Society, 19(3). 
Hutagalung, E. N., \& Ratnawati, K. (2013). Analisa Rasio Keuangan terhadap Kinerja Bank Umum di Indonesia. Jurnal Aplikasi Manajemen, 11(1), 122-130.

Iramani, R. R., Muazaroh, M., \& Mongid, A. (2018). Positive contribution of the good corporate governance rating to stability and performance: Evidence from Indonesia. Problems and Perspectives in Management, 16(2), 1-11.

Irawati, N., Maksum, A., Sadalia, I., \& Muda, I. (2019). Financial performance of Indonesian's banking industry: The role of good corporate governance, capital adequacy ratio, nonperforming loan and size. International Journal of Scientific and Technology Research, 8(4), $22-26$.

Kuncoro, M. (2009). Metode Riset Untuk Bisnis \& Ekonomi. Jakarta: Salemba Empat.

Otoritas Jasa Keuangan. (2021). Laporan Keuangan Perbankan (www.ojk.go.id) diakses 25 Pebruari 2021.

Otoritas Jasa Keuangan. (2021). Peraturan Otoritas Jasa Keuangan Nomor 6/POJK.03/2016, tentang Kegiatan Usaha dan Jaringan Kantor Berdasarkan Modal Inti Bank. Jakarta: Otoritas Jasa Keuangan.

Otoritas Jasa Keuangan. (2021). Statistik Perbankan Indonesia (www.ojk.go.id) diakses 25 Pebruari 2021.

Prasanjaya, A. Y., \& Ramantha, I. W. (2013). Analisis pengaruh rasio CAR, BOPO, LDR dan ukuran perusahaan terhadap profitabilitas bank yang terdaftar di BEI. E-Jurnal Akuntansi, 4(1), 230-245.

Rahayu, S. M., Ramadhanti, W., \& Widodo, T. M. (2018). Analisis Pengaruh Gender Direksi dan Komisaris, Manajemen Laba, Serta Kinerja Perusahaan Terhadap Kompensasi Manajemen Puncak di ASEAN. Deepublish.

Salike, N., \& Ao, B. (2018). Determinants of bank's profitability: role of poor asset quality in Asia. China Finance Review International.

Seemule, M., Sinha, N., \& Ndlovu, T. (2017). Determinants of commercial banks' profitability in Botswana: an empirical analysis. IUP Journal of Bank Management, 16(2), 7.

Subandi, S., \& Ghozali, I. (2013). Determinan efisiensi dan dampaknya terhadap kinerja profitabilitas industri perbankan di Indonesia. Jurnal Keuangan dan Perbankan, 17(1).

Sugiarto, S., \& Lestari, H. S. (2018). Faktor-Faktor yang Mempengaruhi Profitabilitas Bank Pada Bank Konvensional yang Terdaftar di Bursa Efek Indonesia. Jurnal Manajemen dan Pemasaran Jasa, 10(2), 267-280.

Sugiyono. (2015). Metode Penelitian Kuantitatif. Kualitatif dan R\&D. Bandung Alfabeta.

Veithzhal Rivai. (2013). Comercial Bank Management, Manajemen Perbankan dan Teori ke Praktik. Cetakan ke 1. Jakarta: PT. Raja Grafindo Persada. 